\title{
Melatonin Can Strengthen the Effect of Retinoic Acid in HL-60 Cells
}

\author{
Olga Krestinina ${ }^{1, *}$, Roman Fadeev ${ }^{1}$, Alexey Lomovsky ${ }^{1,2}$, Yulia Baburina ${ }^{1}$, \\ Margarita Kobyakova ${ }^{1,2}$ and Vladimir Akatov ${ }^{1}$ \\ 1 Institute of Theoretical and Experimental Biophysics, Russian Academy of Science, Institutskaya St, 3, \\ 142290 Pushchino, Moscow region, Russia; fadeevrs@gmail.com (R.F.); lomovskyalex@gmail.com (A.L.); \\ byul@rambler.ru (Y.B.); ritaaaaa49@gmail.com (M.K.); akatov.vladimir@gmail.com (V.A.) \\ 2 Pushchino State Natural Science Institute, 142290 Pushchino, Moscow region, Russia \\ * Correspondence: ovkres@mail.ru; Tel.: +7-4967-739182; Fax: +7-4967-330553
}

Received: 30 August 2018; Accepted: 20 September 2018; Published: 21 September 2018

\begin{abstract}
Melatonin is produced by the pineal gland. It can be regarded as an anticancer agent and used for combined therapy, owing to its oncostatic, antioxidant, and immunoregulatory activities. Retinoic acid is widely used for the treatment of acute promyelocytic leukemia; however, it has adverse effects on the human organism. We investigated the effect of melatonin and reduced concentrations of retinoic acid on the activation of proliferation in acute promyelocytic leukemiaon a cell model HL-60. The combined effect of these compounds leads to a reduction in the number of cells by $70 \%$ and the index of mitotic activity by $64 \%$. Combined treatment with melatonin and retinoic acid decreased the expression of the Bcl-2. The mitochondrial isoform VDAC1 can be a target in the treatment of different tumors. The combined effect of and retinoic acid at a low concentration $(10 \mathrm{nM})$ decreased VDAC1 expression. Melatonin in combination with retinoic acid produced a similar effect on the expression of the translocator protein. The coprecipitation of VDAC with $2^{\prime}, 3^{\prime}$-cyclonucleotide-3'-phosphodiesterase implies a possible role of its in cancer development. The combined effect of retinoic acid and melatonin decreased the activity of the electron transport chain complexes. The changes in the activation of proliferation in HL-60 cells, the mitotic index, and Bcl-2 expression under combined effect of retinoic acid $(10 \mathrm{nM})$ with melatonin $(1 \mathrm{mM})$ are similar to changes that are induced by $1 \mu \mathrm{M}$ retinoic acid. Our results suggest that MEL is able to improve the action the other chemotherapeutic agent.
\end{abstract}

Keywords: acute promyelocytic leukemia; HL-60 cells; melatonin; apoptosis; retinoic acid; voltage dependent anion channel-1; translocator protein; $2^{\prime}, 3^{\prime}$-cyclonucleotide- $3^{\prime}$-phosphodiesterase

\section{Introduction}

The oncological diseases are a high-priority problem in the industrial and developing countries. New approaches to the treatment of malignant tumors are one of the most pressing problems of medicine. Therefore, the research in this area should be aimed at finding new drugs and/or combining the already known drugs to prevent the growth and development of malignant tumors. Melatonin (MEL), $\mathrm{N}$-acetyl-5-methoxytryptamine, a hormone, is a derivative of the biogenic amine serotonin, which, in turn, is synthesized from tryptophan. MEL is secreted by the pineal gland and other tissues [1,2]. It has been reported that MEL produces an anticancer effect in different types of tumor cells [3,4]. The abnormal levels of MEL in cancer patients indicate its significant role in oncogenesis [5].

In response to oxidative stress, or when the mitochondrial matrix is overloaded by calcium, permeability of the inner membrane of mitochondria increases, and a nonspecific pore (mPTP) forms [6]. The regulators/modulators of $\mathrm{mPTP}$ are the voltage-dependent anion channel (VDAC), adenine nucleotide translocase, the translocator protein (TSPO), and other proteins. VDAC is a $32 \mathrm{kDa}$ protein 
comprising three isoforms in human (VDAC1, VDAC2, VDAC3). VDAC1 is the most abundant isoform [7]. Mathupala et al. showed that some tumor cells exhibit a high level of VDAC1 expression, and the protein can be considered to be an anticancer target [8].

TSPO is a partner of VDAC. In various types of cancers, including large bowel [9], brain [10], mammary gland [11], ovary [12,13], and liver [14], the expression of TSPO is increased.

In addition, some investigators believe that TSPO plays a key role in cancer cell growth [15-18]. We have recently identified a protein $\left(2^{\prime}, 3^{\prime}\right.$-cyclonucleotide-3'-phosphodiesterase (CNPase)) in rat brain and liver mitochondria, namely, in mitochondrial membrane fractions, which can regulate the mPTP function [19]. Later, Yang et al. presented morphological and molecular evidence of the enhanced expression of CNPase in activated microglia [20]. Microglial cells are activated in response to pathological processes to protect the brain against damage [21,22], and CNPase is probably involved in these processes.

Acute promyelocytic leukemia (APL) is a variety of acute myelocytic leukemia, which is mainly characterized by the chromosomal translocation of the gene of the retinoic acid receptor-alpha [23]. Koh et al. showed that MEL enhances cytotoxicity, PARP (poly ADP-ribose polymerase) cleavage, and the activation of caspase and AMPK $\alpha$ (5'-adenosine monophosphate-activated kinase alpha) and suppresses the expression of antiapoptotic proteins, such as $\mathrm{Bcl}-2$ and $\mathrm{Bcl}_{\mathrm{xL}}$ in puromycin-treated HL-60 cells. The authors concluded that MEL might be useful as a sensitizer for chemotherapeutic agents, such as puromycin in APL treatment [24]. The action of MEL described in their work is consistent with the results of the other study, which shows that MEL enhances the efficiency of other chemotherapeutic drugs [25]. Combinatorial therapy with all-trans retinoic acid (ATRA) and conventional chemotherapeutic agents was applied as a potentially useful therapeutic approach to the treatment of APL [26,27]; however, eventual relapses during the long-term treatment diminished their therapeutic effect [28].

In the present work, the combined effect of MEL (at a pharmacological concentration-1 $\mathrm{mM}$ ) and ATRA at a low concentration on the activation of proliferation in HL-60 cells as a model of APL was investigated, and an analysis of the cell cycle in these cells was performed. In addition, we analyzed the alterations in the content of proteins (TSPO, VDAC1, CNPase) and the basic subunits of electron transport chain (ETC) complexes by the action of MEL in combination with ATRA in these cells.

\section{Results}

At first, we analyzed the cytotoxic effects of MEL (Figure 1a) and ATRA (Figure 1b) in HL-60 human leukemic cells. Cells were treated for $96 \mathrm{~h}$ with different concentrations of either MEL $\left(10^{-3}\right.$, $\left.3.3 \times 10^{-4}, 1.1 \times 10^{-4}, 4 \times 10^{-5}, 10^{-5}, 4.1 \times 10^{-6}, 1.4 \times 10^{-5}, 5 \times 10^{-6}, 2 \times 10^{-6} \mathrm{M}\right)$ and ATRA $\left(5 \times 10^{-10}, 4 \times 10^{-9}, 1.3 \times 10^{-8}, 4 \times 10^{-8}, 1.2 \times 10^{-8}, 3.77 \times 10^{-7}, 1.11 \times 10^{-5}, 3.33 \times 10^{-5}, 10^{-5} \mathrm{M}\right)$ for $96 \mathrm{~h}$. In clinical practice, ATRA is used at a concentration of $1 \mu \mathrm{M}$; in the present work, the ATRA concentration was reduced to $10 \mathrm{nM}$ (Figure 1c)., MEL had a significant effect on the viability of HL-60 cells up to the concentration of $1 \mathrm{mM}$ (as shown in Figure 1d). 
(a)<smiles>COc1ccc2[nH]cc(CCNC(C)=O)c2c1</smiles>

(c)

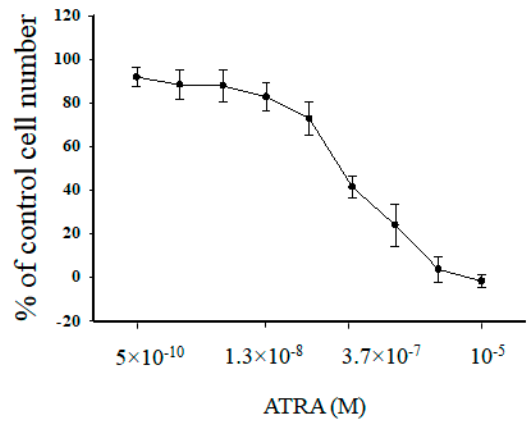

(b)<smiles>CC(C)=CC(C)=C/C=C(C)/C=C/C1=C(C)CCCC1(C)C</smiles>

(d)

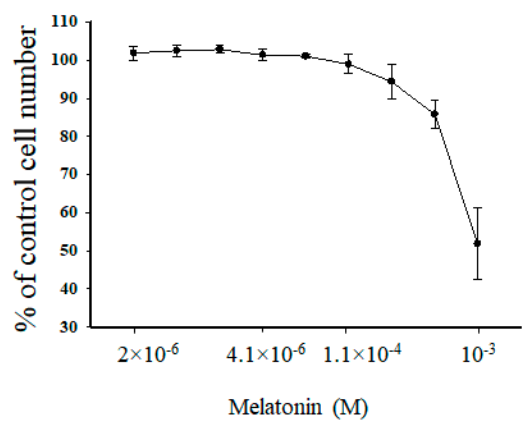

Figure 1. Upper part (a) and (b). Chemical structures of melatonin (MEL) and all-trans retinoic acid (ATRA). (a) MEL, (b) ATRA. Lower part (c) and (d). Concentration dependence of the cytotoxic effects of MEL and ATRA. Cells were seeded in a 96-well plate at a density of $5 \times 10^{3}$ cells per well and treated with indicated concentrations of (a) MEL and (b) ATRA for $96 \mathrm{~h}$. The data are presented as means \pm S.D. of ten separate experiments.

Next, we evaluated the effect of MEL on cell death in HL-60 cells treated with ATRA (10 nM) and MEL at noncytotoxic concentrations $(1 \mathrm{mM})$ for $96 \mathrm{~h}$ (Figure 2). Figure 2a demonstrates the viability of HL-60 cells under different conditions. The relative values of the number of cells are shown in percent. It is seen that the cell viability was reduced in the presence of MEL ( $1 \mathrm{mM})$ and ATRA $(10 \mathrm{nM})$ by $50 \%$ and $20 \%$, respectively, when compared to the control $(100 \%)$. The combined effects of the compounds (ATRA + MEL) led to a $70 \%$ reduction in the number of cells as compared to the control and a $43 \%$ reduction when compared to the experiments with MEL alone. In this process, MEL significant strengthens the effect of ATRA in comparison with control (ATRA $10 \mathrm{nM}$ ).

(a)

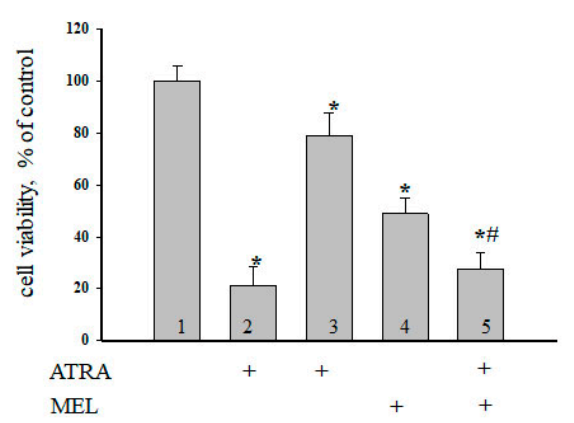

(b)

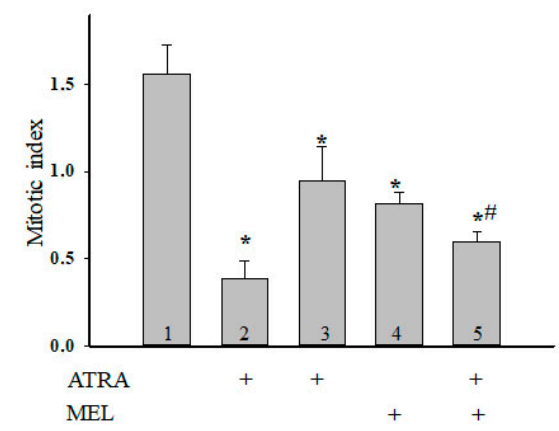

Figure 2. Combined effect of MEL and ATRA on the viability and proliferation status of HL-60 cells. Cells were seeded in a 96-well plate at a density of $5 \times 10^{3}$ cells per well and treated with $1 \mu \mathrm{M}$ ATRA (column 2), and $10 \mathrm{nM}$ ATRA (columns 3) and $1 \mathrm{mM}$ MEL (column 4), and MEL in combination with $10 \mathrm{nM}$ ATRA (column 5); untreated cells (control, column 1). (a) Cell viability in \% relative to the control; (b) The mitotic index (MI) is defined as the ratio between the number of cells in mitosis and the total number of cells. The data are presented as the means \pm S.D. of ten separate experiments. ${ }^{*} p<0.05$ significant difference in values in comparison with the corresponding control, ${ }^{\#} p<0.05$ significant difference in values compared to the value obtained after the addition of MEL alone. 
The mitotic index (MI) is a measure of the proliferation status of a cell population. It is defined as the ratio between the number of cells in mitosis and the total number of cells. Here, we calculated MI of HL-60 cells under different conditions. Figure $2 b$ demonstrates the effect of the compounds on the mitotic activity of cells. It is seen that MI decreased by 50\% in the presence of $1 \mathrm{mM}$ MEL and by $\sim 37 \%$ in the presence of 10 nM ATRA. With the combined effect of the compounds, MI was reduced by $64 \%$ as compared with the control (without treatment) and by $28 \%$ when compared to experiments with MEL alone. These results imply that MEL can enhance the cytotoxicity of ATRA at low concentration in HL-60 human leukemic cells.

Earlier Quintana and coworkers have reported that MEL modulated the induction of apoptosis in hyperthermia-exposed human leukemia cells (U937) [29]. Here, we determined the level of Bcl-2 in our experimental conditions. Figure 3 (upper panel) shows Western blots of Bcl-2 in the lysates of HL-60 human leukemic cells treated with ATRA $(1 \mu \mathrm{M})$, ATRA $(10 \mathrm{nM})$, MEL $(1 \mathrm{mM})$, and ATRA $(10 \mathrm{nM})$ + MEL $(1 \mathrm{mM})$. A quantitative analysis of the Bcl-2 and Bcl-xL levels are shown in Figure 3 (lower panels). Protein bands were quantified after normalization with respect to $\alpha$-tubulin. The Bcl-2 level in HL-60 cells in the presence of ATRA $(1 \mu \mathrm{M})$ was three times lower, and in the presence of ATRA $(10 \mathrm{nM})$, it was two times lower than in the control. A similar result was obtained after treatment with MEL (1 mM). Interestingly, with the combined effect of MEL and ATRA, $1 \mathrm{mM}$ MEL strengthened the influence of $10 \mathrm{nM}$ ATRA, and the level of antiapoptotic Bcl-2 was reduced approximately threefold when compared with control and by $37 \%$ compared to experiments with MEL alone. The same effects of MEL and ATRA and its combined effect on Bcl-xL level were observed.

(a)

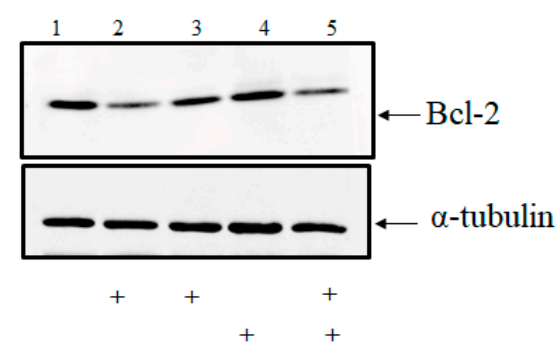

MEL

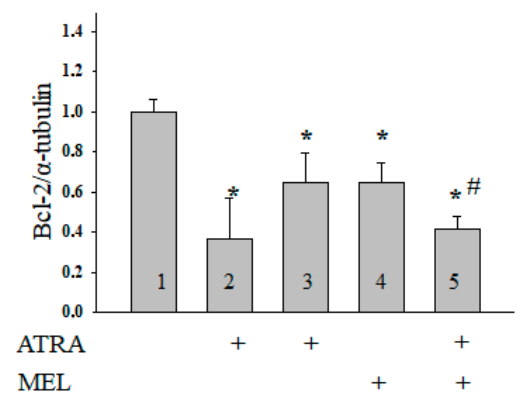

(b)
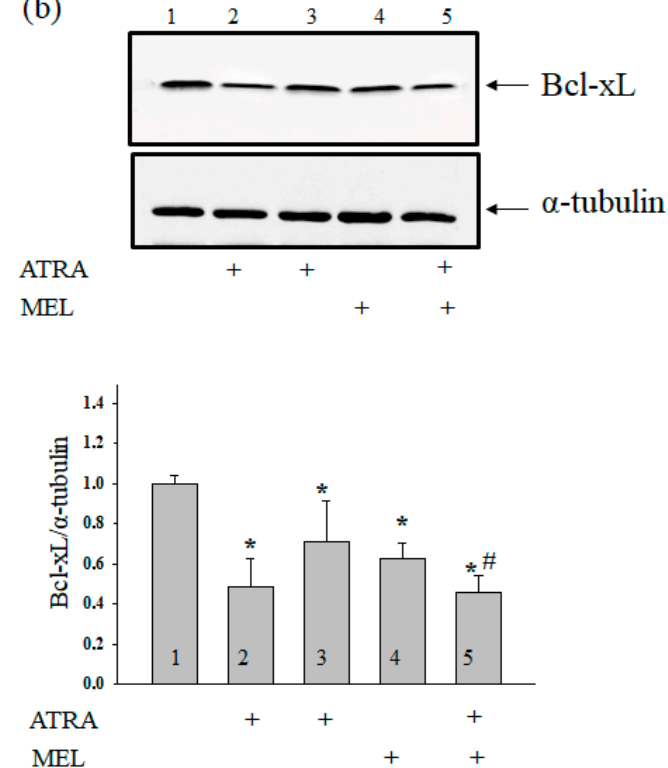

Figure 3. Combined effect of MEL and ATRA on the level of Bcl-2 (a) and Bcl-xL (b) proteins in HL-60 cells. Cells were seeded in a 96-well plate at a density of $5 \times 10^{3}$ cells per well and treated with $1 \mu \mathrm{M}$ ATRA (column 2), and $10 \mathrm{nM}$ ATRA (columns 3) and $1 \mathrm{mM}$ MEL (column 4), and MEL in combination with 10 nM ATRA (column 5); untreated cells (control, column 1). Protein samples were extracted and subjected to Western blot for Bcl-2 and Bcl-xL detection. Immunodetection of $\alpha$-tubulin was used as a loading control. Upper parts-immunostaining of Bcl-2, Bcl-xL and $\alpha$-tubulin. Lower part-quantitation of immunostaining using computer-assisted densitometry. Bar graphs represent the proteins levels in relative units. The protein level in a cell lysate without any addition was taken to be unity and served as a control. The data are presented as the means \pm S.D. of five separate experiments. ${ }^{*} p<0.05$ significant difference in the protein level compared with the corresponding control, ${ }^{\#} p<0.05$ significant difference in the protein level compared to the value that was obtained in the presence of MEL alone. 
Since VDAC initiates apoptotic-signaling cascades [30] and VDAC1 is an anticancer target [8], we determined the VDAC1 content in our experimental conditions (Figure 4a). In cells that were treated with $1 \mu \mathrm{M}$ ATRA, the VDAC1 level was reduced by $50 \%$, while $10 \mathrm{nM}$ ATRA did not affect VDAC1 expression compared with the control. Treatment with MEL diminished the level of VDAC1 by $\sim 30 \%$, but the addition of MEL to cells that were treated with ATRA (10 nM) decreased the expression of VDAC1 by $\sim 30 \%$. Because VDAC is tightly associated with TSPO [31], we determined whether the TSPO level changes under the experimental conditions used. Figure $4 \mathrm{~b}$ demonstrates that, in the presence of ATRA $(1 \mu \mathrm{M})$ and MEL, the TSPO content decreased by $\sim 24 \%$ and $\sim 16 \%$, respectively, while ATRA $(10 \mathrm{nM})$ did not change the TSPO level in comparison with the control. The addition of MEL in combination with ATRA ( $10 \mathrm{nM}$ ) to HL-60 cells led to a $40 \%$ decline in TSPO expression as compared with control and to a $36 \%$ decrease when compared to experiments with MEL alone. We have reported earlier that VDAC coprecipitates with CNPase [32].
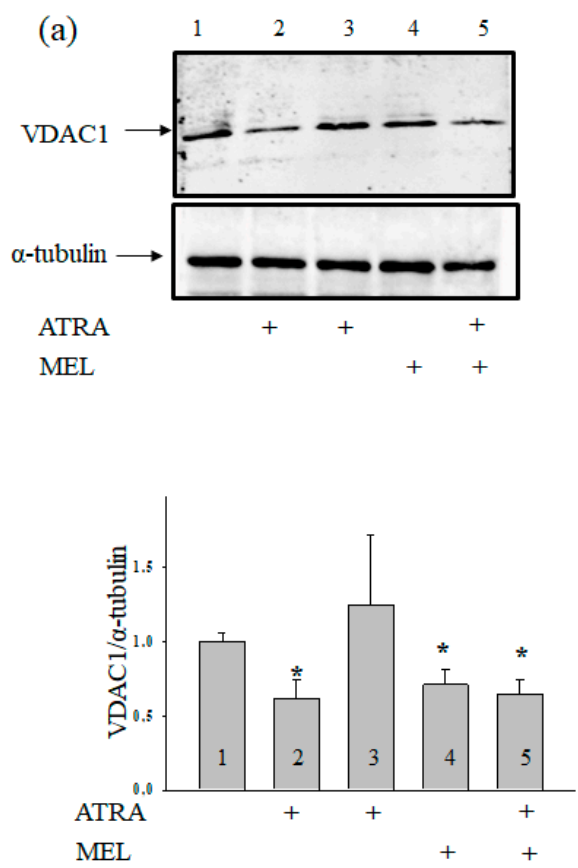

(b)
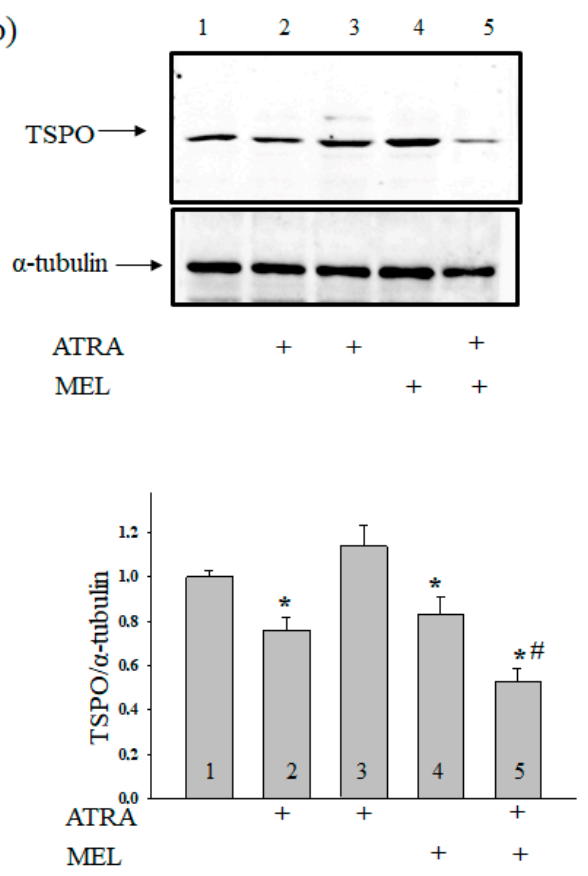

Figure 4. Combined effect of MEL and ATRA on the level of TSPO and VDAC1 in HL-60 cells. Cells were seeded in a 96-well plate at a density of $5 \times 10^{3}$ cells per well and treated with $1 \mu \mathrm{M}$ ATRA (column 2), and $10 \mathrm{nM}$ ATRA (columns 3) and $1 \mathrm{mM}$ MEL (column 4), and MEL in combination with $10 \mathrm{nM}$ ATRA (column 5); untreated cells (control, column 1). Immunodetection of $\alpha$-tubulin was used as a loading control. (a) Immunostaining (upper part) and quantitation (lower part) of the protein level of VDAC1; (b)-of TSPO. Bar graphs represent the levels of appropriate proteins in relative units. The protein level in a cell lysate without any addition was taken to be unity and served as a control. The data are presented as means \pm S.D. of five separate experiments. ${ }^{*} p<0.05$ significant difference in protein level in comparison with corresponding control, ${ }^{\#} p<0.05$ significant difference in the protein level compared to the value obtained in the presence of MEL alone.

Moreover, we have found that MEL is capable of retain CNPase inside mitochondria to protect cells against damage [33]. In the present work, we determined whether the combined application of MEL and ATRA affects the CNPase level (Figure 5). ATRA at different concentrations did not change the CNPase content in HL-60 cells in comparison with the control. MEL increased the CNPase level by $55 \%$ in comparison with the control. MEL, in combination with ATRA $(10 \mathrm{nM})$, upregulated the CNPase content about twofold when compared with control and by $32 \%$ as compared to experiments with MEL alone. Acuna-Castroviejo D. and co-worker showed that MEL improved the activity of ETC, reducing the formation of ROS at the level of complexes I and IV [34]. We analyzed the alterations in 
the content of the basic subunits of ETC complexes by the action of MEL in combination with ATRA in HL-60 cells (Figure 6). We found that the level of alpha subunit of Complex V decreased after the combined treatment with ATRA and MEL by 25\%. MEL diminished the content of the Core protein 2 of Complex III by 16\%; however, the addition of MEL strengthened the effect of ATRA (10 nM) with the result that the level of the Core protein 2 decreased by $32 \%$ when compared with control and by $31 \%$ as compared to experiments with MEL alone. We noticed a decline in the level of the subunit of Complex IV by $27 \%$ in the presence of ATRA $(1 \mu \mathrm{M})$, by $26 \%$ in the presence of MEL, and by $65 \%$ with the combined effect of ATRA (10 nM) and MEL compared with control. However, the level of the subunit of Complex IV in the case of ATRA $(10 \mathrm{nM})$ combined with MEL decreased by $56 \%$ ascompared to experiments with MEL alone. The level of the subunit of Complex II decreased in the presence of ATRA (10 nM), MEL, and a combination of ATRA ( $10 \mathrm{nM})$ with MEL by 22, 23, and 40\%, respectively. After the exposure of cells to a combination of $10 \mathrm{nM}$ ATRA with MEL, the content of the subunit of Complex I declined by $46 \%$ as compared with the control and by $53 \%$ when compared to experiments with MEL alone.
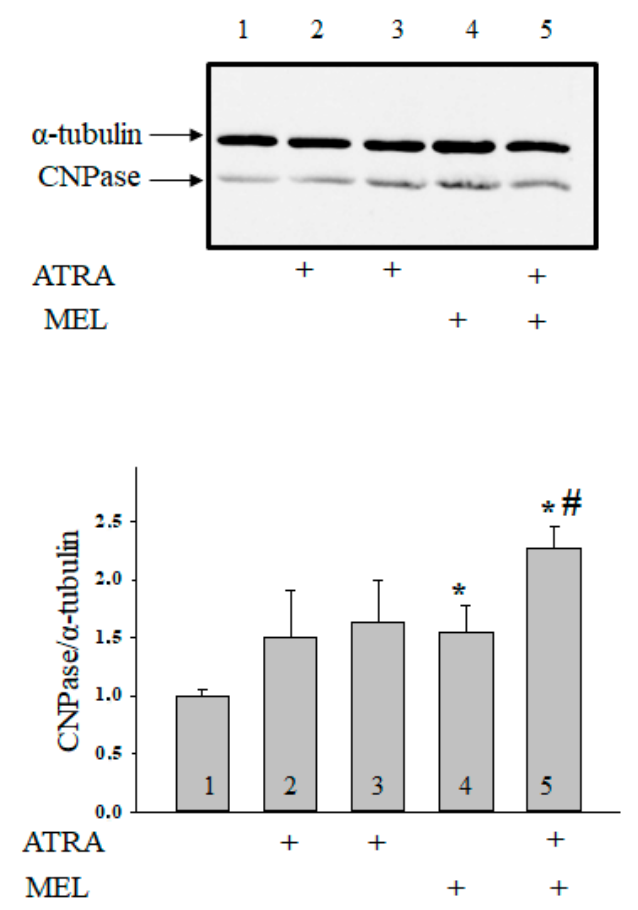

Figure 5. Combined effect of MEL and ATRA on the level of CNPase in HL-60 cells. Cells were seeded in a 96-well plate at a density of $5 \times 10^{3}$ cells per well and treated with $1 \mu \mathrm{M}$ ATRA (column 2), and $10 \mathrm{nM}$ ATRA (columns 3) and $1 \mathrm{mM}$ MEL (column 4), and MEL in combination with $10 \mathrm{nM}$ ATRA (column 5); untreated cells (control, column 1). Protein samples were extracted and subjected to Western blot for CNPase detection. The immunodetection of $\alpha$-tubulin was used as a loading control. Upper part-immunostaining of CNPase and $\alpha$-tubulin. Lower part-quantitation of immunostaining using computer-assisted densitometry. Bar graphs represent the Bcl-2 level in relative units. The protein level in a cell lysate without any addition was taken to be unity and served as a control. The data are presented as means \pm S.D. of five separate experiments. ${ }^{*} p<0.05$ significant difference in protein level in comparison with corresponding control, ${ }^{\#} p<0.05$ significant difference in the protein level compared to the value obtained in the presence of MEL alone. 
(a)

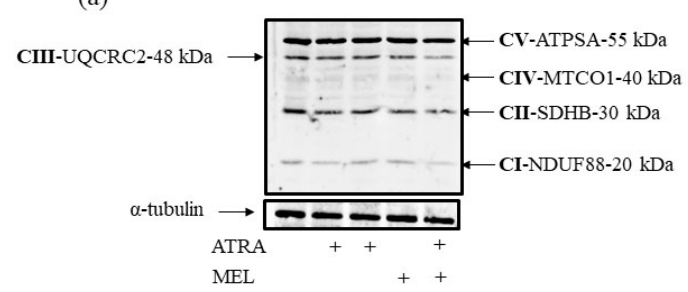

(c)

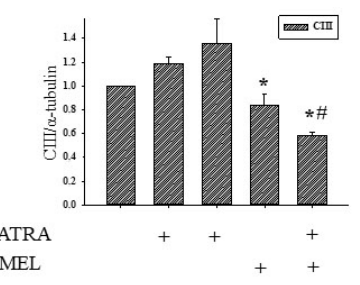

(d)

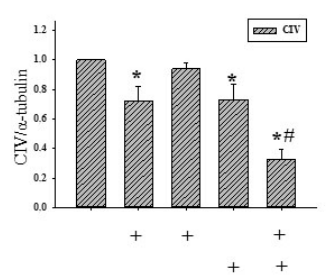

(b)

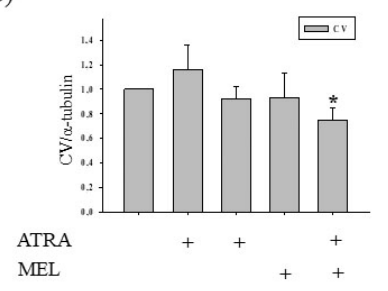

(f)

Figure 6. The effect of MEL and ATRA on the mitochondrial respiratory chain complexes in HL-60 cells. Cells were seeded in a 96-well plate at a density of $5 \times 10^{3}$ cells per well and treated with $1 \mu \mathrm{M}$ ATRA (column 2), and $10 \mathrm{nM}$ ATRA (columns 3) and $1 \mathrm{mM}$ MEL (column 4), and MEL in combination with 10 nM ATRA (column 5); untreated cells (control, column 1). Protein samples were extracted and subjected to Western blotting. Changes in mitochondrial complexes were detected using, the Total OXPHOS Rodent WB Antibody Cocktail. The immunodetection of $\alpha$-tubulin was used as a loading control. (a) Immunostaining with OXPHOS antibody cocktail and $\alpha$-tubulin; (b-f)-quantification of immunostaining using computer-assisted densitometry. Bar graphs represent the levels of appropriate complexes (I-V) in relative units. The protein level in a cell lysate without any addition was taken to be unity and served as a control. The data are presented as means \pm S.D. of five separate experiments. ${ }^{*} p<0.05$ significant difference in protein level in comparison with the corresponding control, ${ }^{*} p<0.05$ significant difference in the protein level compared to the value obtained in the presence of MEL alone.

\section{Discussion}

The combination therapy using ATRA and chemotherapeutic drugs has significantly increased the remission and the disease-free survival rates [35,36], the harmful effects of ATRA (e.g., ATRA syndrome) and the toxicity of chemotherapeutic agents still remain urgent problems in the treatment of APL [37,38]. MEL produces a beneficial effect on different types of cancers, including pancreatic, liver, and prostate cancer cells [39-42]. It is known that MEL induces apoptosis in HL-60 cells [43,44]. In addition, MEL enhances the efficiency of other chemotherapeutic drugs [24]; however, the information on the combination therapy of MEL with ATRA is very scarce. Here, we investigated the effect of MEL in combination with ATRA at a concentration that is lower than used in medicinal practice $(10 \mathrm{nM})$ on the activation of proliferation in HL-60 cells. We found that $1 \mu \mathrm{M}$ ATRA exhibits a substantial cytotoxicity against HL-60 cells, while a concentration of $10 \mathrm{nM}$ does not influence the cell viability. MEL reduced the cell viability; however, the combined treatment of MEL (1 mM) and ATRA (10 nM) at nontoxic concentrations enhanced the cytotoxicity against HL-60 cells as compared to the treatment with MEL or ATRA (10 nM) taken alone. The changes in the activation of proliferation in HL-60 cells and the mitotic index under combined effect of ATRA $(10 \mathrm{nM})$ with MEL $(1 \mathrm{mM})$ are similar to those that were observed by the influence of $1 \mu \mathrm{M}$ ATRA. Furthermore, the combined treatment of MEL with ATRA significantly suppressed the expression of the antiapoptotic protein Bcl-2 as compared to the expression of the protein after the treatment with ATRA $(10 \mathrm{nM})$ or MEL alone. The changes in the expression of Bcl-2 under the combined effect of ATPA $(10 \mathrm{nM})$ with MEL were similar to those occurring in the presence of ATPA $(1 \mu \mathrm{M})$. Overexpression of Bcl-2 family proteins CED-9 and Bcl-xL can induce mitochondrial fusion in mammalian cells [45]. Bcl-xL can also accelerate mitochondrial fission in mammalian neurons, thereby accelerating mitochondrial dynamics [46]. It is possible that 
a decrease in the level of Bcl-2 by the action of MEL, ATRA, and a combination of MEL with ATRA triggers the apoptosis signaling cascade. The regulation of the cellular apoptosis via the mitochondrial permeability transition pore (mPTP) is the balance between pro- and anti-apoptotic Bcl-2 family proteins [47]. The initial stage of apoptosis is the formation of $\mathrm{MPTP}$ in the inner mitochondrial membrane, which is accompanied by a membrane potential drop, mitochondrial swelling, and release of cytochrome $c$ from the intermembrane space to the cytosol via the permeabilization of the outer mitochondrial membrane [48]. Molecular interactions of VDAC with pro- and antiapoptotic proteins of the outer mitochondrial membrane are multi-faceted and they can both promote and prevent cell death. The mitochondrial VDAC is a basic component that can be targeted in tumors. VDAC initiates apoptotic signaling cascades and hence is capable of depleting the metabolic fluxes of tumors [30]. We found that the expression of VDAC1 in HL-60 cells decreased after the combined treatment with ATRA $(10 \mathrm{nM})$ and MEL, indicating changes in the regulation of metabolic and energetic functions of mitochondria and in the fate of cancer cells. The changes in the expression of VDAC1 under the combined effect of ATPA $(10 \mathrm{nM})$ with MEL were similar to those that were occurring in the presence of ATPA $(1 \mu \mathrm{M})$. TSPO is not only a partner but also a modulator of VDAC [49]. It has been established that TSPO is involved in the regulation of cellular proliferation and apoptosis in gliomas, which are highly aggressive malignant cancers with a poor prognosis [50]. TSPO is colocolized with VDAC and forms a firmly complex with this protein. It might modulate VDAC conductance and regulate mitochondrial functions under different physiological and pathophysiologic conditions [31].

Many investigators reported that TSPO expression increases in different types of cancer, including brain tumor and glioma [51-53]. The overexpression of TSPO correlates with tumorogenicity [54]. We observed a diminished TSPO expression in HL-60 cells that were treated with ATRA $(1 \mu \mathrm{M})$, MEL, and ATRA $(10 \mathrm{nM})$ combined with MEL. Presumably, the decrease in TSPO expression under these conditions causes a reduction in tumorogenicity.

In the outer membrane of mitochondria, VDAC1 is a protein that interacts with cytosol, endoplasmic reticulum, and mitochondrial proteins. Together, they regulate signaling and metabolic pathways, triggering cell death [55]. Recently, we found that VDAC co-precipitated with CNPase localized in both the outer and inner membrane [19,32]. We showed that CNPase can participate in the regulation of mPTP functioning [19]. It is known that CNPase expression in activated microglia can be upregulated in response to brain injury [20]. It remains unknown whether CNPase is involved in cancer development. There is evidence indicating that a decrease in TSPO expression is accompanied by an increase in the level of CNPase in mitochondria that are isolated from glioma C6 with TSPO knockdown [in press]. These data agree with the results obtained in the present study, which indicate that $1 \mu \mathrm{M}$ ATRA and $10 \mathrm{nM}$ ATRA combined with MEL increase CNPase expression, while the expression of TSPO in these conditions decreases. Our results suppose a possible involvement of CNPase in cancer development. Further research is needed to establish the mechanisms by which CNPase is involved in cancer progress.

Recently, we showed that CNPase is associated with ETC complexes [32]. MEL is able to improve the activity of the ETC, thereby increasing the activity of the CI and the CIV of the mitochondrial ETC in a time-dependent manner $[34,56]$. High activity of mitochondrial complexes is necessary for the normal functioning of cells. In our case, the activity of ETC complexes in HL-60 cells should be reduced to prevent tumor development. The combined influence of ATRA (10 nM) with MEL decreased the expression of the subunits of ETC complexes, and hence their activity.

In summary, MEL in combination with retinoic acid $(10 \mathrm{nM})$ increased the cytotoxicity of ATRA toward HL-60 cells and suppressed the expression of antiapoptotic Bcl-2 protein. The changes in the activation of proliferation in HL-60 cells, the mitotic index, and Bcl-2 expression under combined effect of ATRA $(10 \mathrm{nM})$ with MEL $(1 \mathrm{mM})$ are similar to changes that are induced by $1 \mu \mathrm{M}$ ATRA. The expression of VDAC1 and TSPO decreased in these conditions, whereas the CNPase expression was enhanced. We suppose that these proteins participate in cancer development. Moreover, MEL in combination with retinoic acid decreased the expression of the subunits of complexes, thereby 
reducing their activity. Overall, our findings suggest that MEL is capable of enhancing the action of other chemotherapeutic agents and can be used in novel strategies in cancer therapy.

\section{Materials and Methods}

\subsection{Chemicals and Reagents}

MEL (N-acetyl-5-methoxytryptamine), resazurin sodium salt, propidium iodide (PI), and a protease/phosphatase inhibitor cocktail were purchased from Sigma-Aldrich (St. Louis, MO, USA). The enhanced chemiluminescence (ECL) detection reagent was purchased from Bio-Rad (Hercules, CA, USA). MEL was dissolved in ethanol.

\subsection{Cell Culture}

Human promyelocytic leukemia HL-60 cells (CCL-240) were derived from ATCC (Manassas, VA, USA). Cells were grown in RPMI 1640 medium (Sigma-Aldrich, USA) supplemented with 20\% heat-inactivated fetal bovine serum (Gibco, Grand Island, NY, USA) and $40 \mu \mathrm{g} / \mathrm{mL}$ of gentamycin sulfate (Sigma-Aldrich, USA) at $37{ }^{\circ} \mathrm{C}$ under conditions of $95 \%$ air humidity and $5 \% \mathrm{CO}_{2}$. The cultures exhibited characteristic doubling times of approximately $24 \mathrm{~h}$.

\subsection{Cell Viability Assay}

The viability of cells was evaluated while using the resazurin cell viability assay. In brief, cells were seeded in a 96-well plate at a density of $5 \times 10^{3}$ cells per well. After $24 \mathrm{~h}$, cells were treated with MEL and ATRA at specified doses. Then, $24 \mathrm{~h}$ after the treatments, resazurin (Sigma-Aldrich) at a final concentration of $100 \mu \mathrm{g} / \mathrm{mL}$ was added into each well, and the cells were incubated for $4 \mathrm{~h}$ at $37^{\circ} \mathrm{C}$. Treatments were carried out in triplicate. Fluorescent intensity was measured by a microplate reader Infinite F200 (Tecan, Grodig, Austria) at an excitation wavelength of $535 \mathrm{~nm}$ and emission wavelength of $595 \mathrm{~nm}$. The data are presented as the percentage of control cells (untreated samples).

\subsection{Cell Cycle Analysis}

After treatment, the cells $\left(10^{6}\right)$ were washed with PBS and fixed in $70 \%$ ethanol for $2 \mathrm{~h}$ at RT. The cells were again rinsed with PBS and resuspended in $500 \mu \mathrm{L}$ of PBS containing $10 \mu \mathrm{g} / \mathrm{mL}$ of PI and $50 \mu \mathrm{g} / \mathrm{mL}$ of RNase. The samples were kept in the dark at RT for $30 \mathrm{~min}$ and analyzed by an Accuri C6 flow cytometry (BD Bioscience, San Jose, CA, USA). The distribution of cells in different phases of the cell cycle was estimated by ModFit LT soft (Verity Software House, Topsham, ME, USA).

\subsection{Determination of the Mitotic Index}

Mitotic activity was determined, as follows: cells incubated for $96 \mathrm{~h}$ under different conditions were centrifuged $(250 \times g, 10 \mathrm{~min})$, resuspended in PBS, and fixed with $70 \%$ ethanol (30 $\mathrm{min}, \mathrm{RT})$. Then, fixed cells were stained with bisBenzimide H33342 (Sigma-Aldrich), and mitotic cells were calculated while using a DM 6000 fluorescent microscope (Leica, Germany). The mitotic index (MI) was determined from the formula $\mathrm{MI}=(\mathrm{P}+\mathrm{M}+\mathrm{A}+\mathrm{T}) / \mathrm{N}$, where $\mathrm{P}+\mathrm{M}+\mathrm{A}+\mathrm{T}$ is the sum of all cells in phases: prophase, metaphase, anaphase, and telophase, respectively, and $\mathrm{N}$ is the total number of cells.

\subsection{Cell Growth Assays}

Cell growth was estimated by counting cells at different time points after treatment. Cells were collected by centrifugation for $10 \mathrm{~min}$ at $250 \times g$ and washed with PBS. Then, the cells were stained with $0.4 \%$ trypan blue (Sigma-Aldrich) to evaluate the cell number and cell viability. Three samples per group were counted in each experiment, and the experiments were performed at least in triplicate. 


\subsection{Electrophoresis and Western Blot Analysis}

HL-60 cells $\left(2 \times 10^{5}\right.$ cells $\left./ \mathrm{mL}\right)$ treated with MEL and/or ATRA were harvested, washed with ice-cold PBS twice, and lysed in lysis buffer (50 mM Tris- $\mathrm{HCl}$ (pH 7.4), $150 \mathrm{mM} \mathrm{NaCl}, 1 \%$ Triton X-100, $0.1 \%$ SDS, $1 \mathrm{mM}$ EDTA, $1 \mathrm{mM} \mathrm{Na}_{3} \mathrm{VO}_{4}$, and $1 \mathrm{mM} \mathrm{NaF}$ ) supplemented with proteinase/phosphatase inhibitors. The extracts were incubated on ice for $30 \mathrm{~min}$ and then centrifuged at $13,000 \times g$ for $20 \mathrm{~min}$ at $4{ }^{\circ} \mathrm{C}$ The supernatants were collected and quantified for protein concentration by using the Bradford protein assay. Then, the supernatants were solubilized by $4 \times$ Laemmli sample buffer (Bio-Rad). To prepare samples for the determination of the level of OxPhos Complexes, the aliquots $(2 \mathrm{mg} / \mathrm{mL})$ of cell lysates were heated to $37^{\circ} \mathrm{C}$ for $3 \mathrm{~min}$. To determine the level of mitochondrial proteins, the samples were heated to $95^{\circ} \mathrm{C}$ for $5 \mathrm{~min}$ and applied to the gel. Protein samples were separated by $12.5 \%$ SDS-PAGE and transferred to a nitrocellulose membrane at $300 \mathrm{~mA}$ for $1 \mathrm{~h}$. The membrane was blocked in Roti-block solution for $1 \mathrm{~h}$ at room temperature then incubated with the primary antibody at $4{ }^{\circ} \mathrm{C}$ overnight and then with an HRP-conjugated secondary antibody. The monoclonal anti-CNPase antibody (anti-CNPase $\mathrm{Ab}$ ) was obtained as described [57], the polyclonal TSPO antibody was from Abcam polyclonal Bcl-xL antybody was from Cell Signalling and the monoclonal Bcl-2 antibody was from Santa Cruz. Alterations in the level of subunits of ETC complexes were determined while using a Total Oxphos Rodent WB Antibody Cocktail (Abcam). The Oxphos Antibody Cocktail consists of complex V alpha subunit (CV-ATP5A-55 kDa), complex III core protein 2 (CIII-UQCRC2-48 kDa), complex IV subunit I (CIV-MTCO1-40 kDa), complex II subunit 30 (CII-SDHB-30 kDa), and complex I subunit NDUF88-20 kDa (CI-NDUFB8). The $\alpha$-tubulin antibody (1:1000 dilution; Cell Signaling, Danvers, MA, USA) was used as a loading control. The blot was detected by an ECL detection system (ChemiDoc Touch Imaging System, Bio-Rad). Protein bands were quantified by densitometry (Image Lab program).

\subsection{Statistical Analysis}

All data were presented as means \pm S.D. Statistical significance was verified by the Student's $t$-test using the Sigmaplot software (Systat Software Inc., San Jose, CA, USA).

Author Contributions: Conceptualization, O.K. and V.A.; Methodology, Y.B. and R.F.; Software, Y.B.; Validation, M.K., A.L. and R.F.; Formal Analysis, V.A.; Investigation, A.L. and M.K.; Writing-Original Draft Preparation, O.K.; Writing-Review \& Editing, V.A.; Visualization, R.F. and Y.B.; Supervision, O.K.; Funding Acquisition, O.K. and V.A.

Funding: This research was funded by the Russian Foundation for Basic Research project no. 17-04-00747 and the Russian Federation Government (N14.Z50.31.0028).

Conflicts of Interest: The authors declare no conflict of interest.

\section{References}

1. Stehle, J.H.; Saade, A.; Rawashdeh, O.; Ackermann, K.; Jilg, A.; Sebesteny, T.; Maronde, E. A survey of molecular details in the human pineal gland in the light of phylogeny, structure, function and chronobiological diseases. J. Pineal Res. 2011, 51, 17-43. [CrossRef] [PubMed]

2. Carlberg, C. Gene regulation by melatonin. Ann. N. Y. Acad. Sci. 2000, 917, 387-396. [CrossRef] [PubMed]

3. Bizzarri, M.; Proietti, S.; Cucina, A.; Reiter, R.J. Molecular mechanisms of the pro-apoptotic actions of melatonin in cancer: A review. Expert Opin. Ther. Targets 2013, 17, 1483-1496. [CrossRef] [PubMed]

4. Vijayalaxmi; Thomas, C.R., Jr.; Reiter, R.J.; Herman, T.S. Melatonin: From basic research to cancer treatment clinics. J. Clin. Oncol. 2002, 20, 2575-2601. [CrossRef] [PubMed]

5. Shiu, S.Y. Towards rational and evidence-based use of melatonin in prostate cancer prevention and treatment. J. Pineal Res. 2007, 43, 1-9. [CrossRef] [PubMed]

6. Bernardi, P. The mitochondrial permeability transition pore: A mystery solved? Front. Physiol. $2013,4,95$. [CrossRef] [PubMed] 
7. Bayrhuber, M.; Meins, T.; Habeck, M.; Becker, S.; Giller, K.; Villinger, S.; Vonrhein, C.; Griesinger, C.; Zweckstetter, M.; Zeth, K. Structure of the human voltage-dependent anion channel. Proc. Natl. Acad. Sci. USA 2008, 105, 15370-15375. [CrossRef] [PubMed]

8. Mathupala, S.P.; Pedersen, P.L. Voltage dependent anion channel-1 (VDAC-1) as an anti-cancer target. Cancer Biol. Ther. 2010, 9, 1053-1056. [CrossRef] [PubMed]

9. Katz, Y.; Eitan, A.; Gavish, M. Increase in peripheral benzodiazepine binding sites in colonic adenocarcinoma. Oncology 1990, 47, 139-142. [CrossRef] [PubMed]

10. Cornu, P.; Benavides, J.; Scatton, B.; Hauw, J.J.; Philippon, J. Increase in omega 3 (peripheral-type benzodiazepine) binding site densities in different types of human brain tumours. A quantitative autoradiography study. Acta Neurochir. (Wien) 1992, 119, 146-152. [CrossRef] [PubMed]

11. Hardwick, M.; Fertikh, D.; Culty, M.; Li, H.; Vidic, B.; Papadopoulos, V. Peripheral-type benzodiazepine receptor (PBR) in human breast cancer: Correlation of breast cancer cell aggressive phenotype with PBR expression, nuclear localization, and PBR-mediated cell proliferation and nuclear transport of cholesterol. Cancer Res. 1999, 59, 831-842. [PubMed]

12. Batra, S.; Iosif, C.S. Elevated concentrations of mitochondrial peripheral benzodiazepine receptors in ovarian tumors. Int. J. Oncol. 1998, 12, 1295-1298. [CrossRef] [PubMed]

13. Katz, Y.; Ben-Baruch, G.; Kloog, Y.; Menczer, J.; Gavish, M. Increased density of peripheral benzodiazepinebinding sites in ovarian carcinomas as compared with benign ovarian tumours and normal ovaries. Clin. Sci. (Lond.) 1990, 78, 155-158. [CrossRef] [PubMed]

14. Venturini, I.; Alho, H.; Podkletnova, I.; Corsi, L.; Rybnikova, E.; Pellicci, R.; Baraldi, M.; Pelto-Huikko, M.; Helen, P.; Zeneroli, M.L. Increased expression of peripheral benzodiazepine receptors and diazepam binding inhibitor in human tumors sited in the liver. Life Sci. 1999, 65, 2223-2231. [CrossRef]

15. Beinlich, A.; Strohmeier, R.; Kaufmann, M.; Kuhl, H. Relation of cell proliferation to expression of peripheral benzodiazepine receptors in human breast cancer cell lines. Biochem. Pharmacol. 2000, 60, 397-402. [CrossRef]

16. Ikezaki, K.; Black, K.L. Stimulation of cell growth and DNA synthesis by peripheral benzodiazepine. Cancer Lett. 1990, 49, 115-120. [CrossRef]

17. Landau, M.; Weizman, A.; Zoref-Shani, E.; Beery, E.; Wasseman, L.; Landau, O.; Gavish, M.; Brenner, S.; Nordenberg, J. Antiproliferative and differentiating effects of benzodiazepine receptor ligands on B16 melanoma cells. Biochem. Pharmacol. 1998, 56, 1029-1034. [CrossRef]

18. Wu, X.; Gallo, K.A. The 18-kDa translocator protein (TSPO) disrupts mammary epithelial morphogenesis and promotes breast cancer cell migration. PLOS ONE 2013, 8, e71258. [CrossRef] [PubMed]

19. Azarashvili, T.; Krestinina, O.; Galvita, A.; Grachev, D.; Baburina, Y.; Stricker, R.; Evtodienko, Y.; Reiser, G. $\mathrm{Ca}^{2+}$-dependent permeability transition regulation in rat brain mitochondria by $2^{\prime}, 3^{\prime}$-cyclic nucleotides and 2', 3'-cyclic nucleotide 3'-phosphodiesterase. Am. J. Physiol. Cell Physiol. 2009, 296, C1428-C1439. [CrossRef] [PubMed]

20. Yang, L.; Kan, E.M.; Lu, J.; Wu, C.; Ling, E.A. Expression of 2' '3' -cyclic nucleotide $3^{\prime}$-phosphodiesterase (CNPase) and its roles in activated microglia in vivo and in vitro. J. Neuroinflam. 2014, 11, 148. [CrossRef] [PubMed]

21. Minagar, A.; Shapshak, P.; Fujimura, R.; Ownby, R.; Heyes, M.; Eisdorfer, C. The role of macrophage/microglia and astrocytes in the pathogenesis of three neurologic disorders: HIV-associated dementia, Alzheimer disease, and multiple sclerosis. J. Neurol. Sci. 2002, 202, 13-23. [CrossRef]

22. Dheen, S.T.; Kaur, C.; Ling, E.A. Microglial activation and its implications in the brain diseases. Curr. Med. Chem. 2007, 14, 1189-1197. [CrossRef] [PubMed]

23. Grignani, F.; Fagioli, M.; Alcalay, M.; Longo, L.; Pandolfi, P.P.; Donti, E.; Biondi, A.; Lo Coco, F.; Grignani, F.; Pelicci, P.G. Acute promyelocytic leukemia: From genetics to treatment. Blood 1994, 83, 10-25. [PubMed]

24. Koh, W.; Jeong, S.J.; Lee, H.J.; Ryu, H.G.; Lee, E.O.; Ahn, K.S.; Bae, H.; Kim, S.H. Melatonin promotes puromycin-induced apoptosis with activation of caspase- 3 and $5^{\prime}$-adenosine monophosphate-activated kinase-alpha in human leukemia HL-60 cells. J. Pineal Res. 2011, 50, 367-373. [CrossRef] [PubMed]

25. Reiter, R.J.; Tan, D.X.; Allegra, M. Melatonin: Reducing molecular pathology and dysfunction due to free radicals and associated reactants. Neuro Endocrinol. Lett. 2002, 23, 3-8. [PubMed]

26. Drexler, H.G.; Quentmeier, H.; MacLeod, R.A.; Uphoff, C.C.; Hu, Z.B. Leukemia cell lines: In vitro models for the study of acute promyelocytic leukemia. Leuk. Res. 1995, 19, 681-691. [CrossRef] 
27. Melnick, A.; Licht, J.D. Deconstructing a disease: RARalpha, its fusion partners, and their roles in the pathogenesis of acute promyelocytic leukemia. Blood 1999, 93, 3167-3215. [PubMed]

28. Liu, P.; Han, Z.C. Treatment of acute promyelocytic leukemia and other hematologic malignancies with arsenic trioxide: Review of clinical and basic studies. Int. J. Hematol. 2003, 78, 32-39. [CrossRef] [PubMed]

29. Quintana, C.; Cabrera, J.; Perdomo, J.; Estevez, F.; Loro, J.F.; Reiter, R.J.; Quintana, J. Melatonin enhances hyperthermia-induced apoptotic cell death in human leukemia cells. J. Pineal Res. 2016, 61, 381-395. [CrossRef] [PubMed]

30. Shimizu, S.; Narita, M.; Tsujimoto, Y. Bcl-2 family proteins regulate the release of apoptogenic cytochrome c by the mitochondrial channel VDAC. Nature 1999, 399, 483-487. [CrossRef] [PubMed]

31. McEnery, M.W.; Snowman, A.M.; Trifiletti, R.R.; Snyder, S.H. Isolation of the mitochondrial benzodiazepine receptor: Association with the voltage-dependent anion channel and the adenine nucleotide carrier. Proc. Natl. Acad. Sci. USA 1992, 89, 3170-3174. [CrossRef] [PubMed]

32. Baburina, Y.; Azarashvili, T.; Grachev, D.; Krestinina, O.; Galvita, A.; Stricker, R.; Reiser, G. Mitochondrial $2^{\prime}, 3^{\prime}$-cyclic nucleotide $3^{\prime}$-phosphodiesterase (CNP) interacts with mPTP modulators and functional complexes (I-V) coupled with release of apoptotic factors. Neurochem. Int. 2015, 90, 46-55. [CrossRef] [PubMed]

33. Baburina, Y.; Odinokova, I.; Azarashvili, T.; Akatov, V.; Lemasters, J.J.; Krestinina, O. 2' ,3'-Cyclic nucleotide $3^{\prime}$-phosphodiesterase as a messenger of protection of the mitochondrial function during melatonin treatment in aging. Bba-Biomembranes 2017, 1859, 94-103. [CrossRef] [PubMed]

34. Acuna-Castroviejo, D.; Martin, M.; Macias, M.; Escames, G.; Leon, J.; Khaldy, H.; Reiter, R.J. Melatonin, mitochondria, and cellular bioenergetics. J. Pineal Res. 2001, 30, 65-74. [CrossRef] [PubMed]

35. Sanz, M.A.; Martin, G.; Gonzalez, M.; Leon, A.; Rayon, C.; Rivas, C.; Colomer, D.; Amutio, E.; Capote, F.J.; Milone, G.A.; et al. Risk-adapted treatment of acute promyelocytic leukemia with all-trans-retinoic acid and anthracycline monochemotherapy: A multicenter study by the PETHEMA group. Blood 2004, 103, 1237-1243. [CrossRef] [PubMed]

36. Asou, N.; Kishimoto, Y.; Kiyoi, H.; Okada, M.; Kawai, Y.; Tsuzuki, M.; Horikawa, K.; Matsuda, M.; Shinagawa, K.; Kobayashi, T.; et al. A randomized study with or without intensified maintenance chemotherapy in patients with acute promyelocytic leukemia who have become negative for PML-RARalpha transcript after consolidation therapy: The Japan Adult Leukemia Study Group (JALSG) APL97 study. Blood 2007, 110, 59-66. [CrossRef] [PubMed]

37. Fenaux, P.; De Botton, S. Retinoic acid syndrome. Recognition, prevention and management. Drug. Saf. 1998, 18, 273-279. [CrossRef] [PubMed]

38. Frankel, S.R.; Eardley, A.; Lauwers, G.; Weiss, M.; Warrell, R.P., Jr. The "retinoic acid syndrome" in acute promyelocytic leukemia. Ann. Intern. Med. 1992, 117, 292-296. [CrossRef] [PubMed]

39. Joo, S.S.; Yoo, Y.M. Melatonin induces apoptotic death in LNCaP cells via p38 and JNK pathways: Therapeutic implications for prostate cancer. J. Pineal Res. 2009, 47, 8-14. [CrossRef] [PubMed]

40. Casado-Zapico, S.; Rodriguez-Blanco, J.; Garcia-Santos, G.; Martin, V.; Sanchez-Sanchez, A.M.; Antolin, I.; Rodriguez, C. Synergistic antitumor effect of melatonin with several chemotherapeutic drugs on human Ewing sarcoma cancer cells: Potentiation of the extrinsic apoptotic pathway. J. Pineal Res. 2010, 48, 72-80. [CrossRef] [PubMed]

41. Fan, L.L.; Sun, G.P.; Wei, W.; Wang, Z.G.; Ge, L.; Fu, W.Z.; Wang, H. Melatonin and doxorubicin synergistically induce cell apoptosis in human hepatoma cell lines. World J. Gastroenterol. 2010, 16, 1473-1481. [CrossRef] [PubMed]

42. Leja-Szpak, A.; Jaworek, J.; Pierzchalski, P.; Reiter, R.J. Melatonin induces pro-apoptotic signaling pathway in human pancreatic carcinoma cells (PANC-1). J. Pineal Res. 2010, 49, 248-255. [CrossRef] [PubMed]

43. Rubio, S.; Estevez, F.; Cabrera, J.; Reiter, R.J.; Loro, J.; Quintana, J. Inhibition of proliferation and induction of apoptosis by melatonin in human myeloid HL-60 cells. J. Pineal Res. 2007, 42, 131-138. [CrossRef] [PubMed]

44. Bejarano, I.; Redondo, P.C.; Espino, J.; Rosado, J.A.; Paredes, S.D.; Barriga, C.; Reiter, R.J.; Pariente, J.A.; Rodriguez, A.B. Melatonin induces mitochondrial-mediated apoptosis in human myeloid HL-60 cells. J. Pineal Res. 2009, 46, 392-400. [CrossRef] [PubMed]

45. Delivani, P.; Adrain, C.; Taylor, R.C.; Duriez, P.J.; Martin, S.J. Role for CED-9 and Egl-1 as regulators of mitochondrial fission and fusion dynamics. Mol. Cell 2006, 21, 761-773. [CrossRef] [PubMed] 
46. Berman, S.B.; Chen, Y.B.; Qi, B.; McCaffery, J.M.; Rucker, E.B., 3rd; Goebbels, S.; Nave, K.A.; Arnold, B.A.; Jonas, E.A.; Pineda, F.J.; et al. Bcl-x L increases mitochondrial fission, fusion, and biomass in neurons. J. Cell Biol. 2009, 184, 707-719. [CrossRef] [PubMed]

47. Gogvadze, V.; Orrenius, S.; Zhivotovsky, B. Mitochondria as targets for chemotherapy. Apoptosis 2009, 14, 624-640. [CrossRef] [PubMed]

48. Kroemer, G. Mitochondrial control of apoptosis: An introduction. Biochem. Biophys. Res. Commun. 2003, 304, 433-435. [CrossRef]

49. Krueger, K.E. Molecular and functional properties of mitochondrial benzodiazepine receptors. Biochim. Biophys. Acta 1995, 1241, 453-470. [CrossRef]

50. Veenman, L.; Gavish, M. The role of $18 \mathrm{kDa}$ mitochondrial translocator protein (TSPO) in programmed cell death, and effects of steroids on TSPO expression. Curr. Mol. Med. 2012, 12, 398-412. [PubMed]

51. Black, K.L.; Ikezaki, K.; Santori, E.; Becker, D.P.; Vinters, H.V. Specific High-Affinity Binding of Peripheral Benzodiazepine Receptor Ligands to Brain-Tumors in Rat and Man. Cancer 1990, 65, 93-97. [CrossRef]

52. Ferrarese, C.; Appollonio, I.; Frigo, M.; Gaini, S.M.; Piolti, R.; Frattola, L. Benzodiazepine Receptors and Diazepam-Binding Inhibitor in Human Cerebral-Tumors. Ann. Neurol. 1989, 26, 564-568. [CrossRef] [PubMed]

53. Veenman, L.; Gavish, M. Peripheral-type benzodiazepine receptors: Their implication in brain disease. Drug Dev. Res. 2000, 50, 355-370. [CrossRef]

54. Veenman, L.; Levin, E.; Weisinger, G.; Leschiner, S.; Spanier, I.; Snyder, S.H.; Weizman, A.; Gavish, M. Peripheral-type benzodiazepine receptor density and in vitro tumorigenicity of glioma cell lines. Biochem. Pharmacol. 2004, 68, 689-698. [CrossRef] [PubMed]

55. Shoshan-Barmatz, V.; Mizrachi, D.; Keinan, N. Oligomerization of the mitochondrial protein VDAC1: From structure to function and cancer therapy. Prog. Mol. Biol. Transl. Sci. 2013, 117, 303-334. [PubMed]

56. Martin, M.; Macias, M.; Escames, G.; Leon, J.; Acuna-Castroviejo, D. Melatonin but not vitamins C and E maintains glutathione homeostasis in t-butyl hydroperoxide-induced mitochondrial oxidative stress. FASEB J. 2000, 14, 1677-1679. [CrossRef] [PubMed]

57. Stricker, R.; Lottspeich, F.; Reiser, G. The myelin protein CNP (2' $3^{\prime}$-cyclic nucleotide $3^{\prime}$-phosphodiesterase): Immunoaffinity purification of CNP from pig and rat brain using a monoclonal antibody and phosphorylation of CNP by cyclic nucleotide-dependent protein kinases. Biol. Chem. Hoppe Seyler 1994, 375, 205-209. [PubMed]

(C) 2018 by the authors. Licensee MDPI, Basel, Switzerland. This article is an open access article distributed under the terms and conditions of the Creative Commons Attribution (CC BY) license (http:/ / creativecommons.org/licenses/by/4.0/). 